\title{
FROM SCIENTIFIC SOCIAL MANAGEMENT TO NEOLIBERAL GOVERNMENTALITY? CZECHOSLOVAK SOCIOLOGY AND SOCIAL RESEARCH ON THE WAY FROM AUTHORITARIANISM TO LIBERAL DEMOCRACY, 1969-1989
}

\author{
Michal Kopeček \\ Institute of Contemporary History, Prague \\ Imre Kertész Kolleg, Jena
}

The aim of the present study is to look at official Marxist sociology in Czechoslovakia during the last two decades of communist rule. As one of the central disciplines of governance, sociology had been providing the Party with necessary empirical knowledge about "socialist society" from the 1960s on. The promising boom of the 1960s (Vorríšek 2012), however, was halted by the Warsaw Pact invasion, and the situation of Czechoslovak sociology after 1969 was bleak. A number of scholars - obviously mostly Marxist - who were active in the remarkable renaissance of sociology in the 1960s were purged during the early stages of the consolidation regime. Many important figures such as Pavel Machonin, Miloš Kaláb, or Jaroslav Klofáč were forced to work either in different disciplines (e.g., Kaláb in pedagogy) or in an entirely different field, and often manually (Machonin, Klofác); many others decided for emigration. What followed, especially in the Czech part of the country, was the rise of "second crew" members, such as František Charvát, Antonín Vaněk, František Zich, and Karel Rychtařík, who had not previously had a chance to hold leading posts. There were a few exceptions, though; some outstanding or at least average sociologists, such as Radovan Richta, Jaroslav Kohout, and Blanka and Jindřich Filipec, made a political compromise with Gustáv Husák’s regime. 
In terms of the development of sociology as an autonomous discipline, the 1970s and 1980s in Czechoslovakia must inevitably appear as a decline. Most historical accounts suggest that this is the case, although such a perspective is usually penned by practitioners of the discipline themselves (e.g., Machonin 2005). However, there is another picture as well. Michael Vořŕšek is far from repeating the "traditional" (dissident, formerreform-communist) narrative about twenty years of complete ideological brainwashing and sterility in sociology (Voříšek 2014). He identifies several strata in the field. First, he discerns the official hegemonic layer that preached a return to Marxism-Leninism as a prerequisite for rekindling the genuine Marxist sociological thought that envisaged politically and ideologically engaged partisan sociology (Rychtařík 1971; Sirácky 1979; Sirácky \& Rychtař́k 1976). Second, there was a layer of more or less respected expert "niches" and semi-official sociology that produced, at times, interesting, largely empirical, sociological research. Third, there was sociology - or rather sociological thinking - in dissent and émigré circles. It was especially the former, semi-official, or "grey zone" sociology (Nešpor et al. 2014) that played a crucial role in the fundamental reconfiguration of the field after 1989. Coming from this group, Miloslav Petrusek, one of the founding figures of the sociological renascence in Czechoslovakia in the late 1980s, also offered a more differentiated approach. He noted that sociology always oscillates between two poles: sociology of the status quo, that is, an apologetic sociology that legitimises a given social order, and critical sociology, which fosters critical distance and aims at the fractional or systemic change of a given social order. Although official sociology in totalitarian systems leaned one-sidedly to the apologetic pole, Petrusek argued, it did not cease to exist as a self-standing discipline (Petrusek 2014).

Drawing on these analyses the present paper pays, however, less attention to the intrinsic value of sociological production in the given period and focuses rather on the modus operandi of "apologetic sociology": the ways in which sociological knowledge was used to help manage late socialist society, and how that knowledge was adapted to the changes brought about by perestroika whilst anticipating its own transformation during the early liberal democratic period after 1989. While methodologically based in the history of political and social thought, this approach is also inspired by governmentality studies, the enquiry into genealogies of governance and its social technologies, and by the social scientific knowledge and expertise forming these technologies (Bevir 2010). Since governmentality studies have emerged historically and theoretically to address largely liberal demo- 
cratic societies, and the thrust of the present article is not theoretical but empirical-historical, the inspiration does not translate here into a consequent theoretical application of the conceptual framework of governmentality onto late-communist Czechoslovakia. Furthermore, sociology and social research after 1989 offered and practised a distinctive "therapeutisation" of Czech and Slovak societies and thus contributed to what some Foucault-inspired theoreticians call "neoliberal governmentality" (Lemke 2000; Rose \& Miller 1992) or "neoliberalism as a historical institutional form" (Flew 2014). ${ }^{1}$ This paper here does not endeavour to make such analyses even though it describes and discusses some of the preconditions of this development.

The current view of the state socialist regimes in their late stage has been influenced by the language of dissidents and their conceptualisations, which characterised the regimes by the predicate "neo-Stalinist" until it was replaced in the 1980s by the notion "totalitarian." From the perspective of our research theme these predicates obscure rather than clarify our understanding of the evolution of the regime. It is particularly notable in the Czechoslovak case, as the post-dissident narrative constructs a marked discontinuity between the "reformist" era of the 1960s and the "normalisation" of the 1970s-1980s. From a longer term perspective focusing on governance practices, however, there are two fundamental phases of postStalinist consolidation regimes in Eastern Europe: the Khrushchevist and the Brezhnevist, respectively. The latter actually connects to the former in many aspects, particularly in light of its governance techniques, and its ideological and intellectual substantiation. ${ }^{2}$

To put it schematically, apart from the complex - albeit half-hearted process of de-Stalinisation, Khrushchevism, mainly in its second phase in the first half of the 1960s, provided a new legitimation formula based on a few main elements that expressed the optimistic expectations of a vigorous and decisive jump into the realm of the communist future. First, there was the notion of the "all-people's state" that had purportedly replaced the dictatorship of the proletariat in the advanced phase of socialism leading to the early passage to communism. This concept was later taken over by Brezhnevism. The second aspect concerned the development of various new models of a state-socialist economy, which toyed with ideas of intro-

\footnotetext{
1 All translations of cited fragments are my own.

2 Previous scholarship has perceived Khrushchevism - in contrast to Brezhnev's era - as a selfstanding phase in the history of the Soviet regime, both in terms of its ideological goals and its ambitions (McCauley 1987; Miller \& Féhér 1984; Smith \& Ilic 2011).
} 
ducing market mechanisms as an auxiliary instrument into planned economies (as suggested by reformist economic teams such as those of Evsei Lieberman in the USSR or Ota Šik in Czechoslovakia). Overall economic reforms - let alone public discussion of them - were abandoned during the Brezhnev rule. Yet the ways to economic improvement within the system were always being explored, not merely in the more reformist Hungary or Poland, but also in the outspokenly "orthodox" communist consolidation regimes after 1968, such as that in Czechoslovakia - for example, through the then leading economic paradigm of optimal planning. Finally, the third novel aspect that best represented the technological and futuristic optimism of Khrushchevism was the theory of a "scientific and technological revolution" as a way towards communist modernity under the guidance of the Party. This too had been adopted and adapted in Brezhnev's era.

The Brezhnevist consolidation regimes of the late 1960s and the 1970s differed from Khrushchevism - and even more from its most successful application in East-Central Europe that is Kádárism - in one major aspect: the comeback of stringent ideological orthodoxy in the public sphere and official discourse in response to and repudiation of the reform communist movement of the 1960s. Furthermore, the utopian vision of an early arrival in the communist future had been irrevocably replaced by the down-toearth project of building "advanced socialism." The latter was supposed to be characterised not by the revolutionary charisma of the Party, but by "scientific management of the society" (nauchnoje upravlyenie obschestvom). This concept played an important legitimisation role in the ruling apparatus. It assured the apparatchiks that the changes and possible reforms would only be gradual, without questioning their power and privilege. Yet it also portrayed state socialism as an alternative modernity based on a different, though efficient, use of technological innovation, for which the highly elastic concept of "scientific and technological revolution" was of great value. Hence the "scientific management" of various spheres such as the economy, individual enterprises, and cities - but also Party life, state administration, and social life - came to be of vital concern for the Party and state leadership, including the managerial elites and expert milieus. ${ }^{3}$

\footnotetext{
${ }^{3}$ Scientific management had always been a concern of Soviet leadership and a part of the Soviet ideological package. Sidelined during high Stalinism, it regained power throughout the whole postStalin era, up until the end of the Soviet Union (Beissinger 1988).
} 


\section{/// The Theory of Scientific and Technological Revolution as the Leading Ideological Paradigm}

The reformist era of the 1960s was the golden age of sociology in Sovietised East-Central Europe, as the discipline aspired to offer a critical mirror to societies, and solutions to the emerging crises (Puttkamer 2012; Vorríšek 2012). Yet even in late-communist dictatorships the official social theory preaching a comeback of "genuine Marxism-Leninism" tried to investigate, under the surface of weighty ideological language, some of the most pressing social-political problems, such as the dilemmas of social integration, social cohesion, and governance. In the less "orthodox" countries, i.e., Poland and Hungary, part of this process even took the form of a sui generis political sociology of the socialist state; it was fostered by some of the leading experts and Party activists such as Jerzy Wiatr or Kálmán Kulcsár, but also by some of the sociologists who became dissidents, such as Jadwiga Staniszkis (Garlicki 1998). In most other countries in the Eastern bloc the theory of scientific and technological revolution (STR) became the leading academic-ideological paradigm of the time. ${ }^{4}$ Rooted in the reformist 1960s, the theory contained a lot of Khrushchevist emancipatory elements that had to be brushed away. In Czechoslovakia the STR was famously represented by an interdisciplinary team around philosopher and sociologist Radovan Richta. Their collective monograph, Civilization at the Crossroads, had a dizzying career in Czechoslovakia and internationally at the end of the 1960s (Richta 1966, 1969). Yet even Civilization contained tangible technocratic elements making it into a potential legitimisation resource after 1968. Already during the Prague Spring the publication had been interpreted in different ways: as a substantiation of reform by reform-minded communist elites, but quite moderately, if not conservatively, by many other members of the Party apparatus. The propositions for improved planning and management systems - with the help of modern communication, cybernetics, etc. - and advocacy of "system engineering" matched the prevailing view among both conservative and reformist party circles that the Party should not lose its central political and economic control. As such it provided a reputable scholarly analysis offering a rather

\footnotetext{
${ }^{4}$ Quite a lot of research has emerged in recent years addressing studies of the political future in the East and West, and their interconnection and transnational ties. (See e.g., Andersson 2012; Andersson \& Rindzevičiūtè 2015; Guth 2015; Rindzevičiūtè 2016). The present study, however, focuses on one aspect, namely the promotion of the theory of STR to the main ideological-academic paradigm in late-communist dictatorships.
} 
moderate and widely technocratic solution to the current crisis, along with less moderate futurological hope for communism as a whole. ${ }^{5}$

Given his own undeniable reformist past, Richta found himself in a difficult position at the beginning of the 1970s. He was only saved because of non-negligible Soviet patronage and, in general terms, because of the compatibility of his STR theory with the main Soviet legitimisation formula. In response to the Prague Spring of 1968, Soviet future studies were also heavily curtailed and purged. The Communist Party made clear that it would not allow social scientists and experts to establish any sort of "second party" of social critics (Guth 2015: 364). In Czechoslovakia the adaptation of the STR to the new circumstances involved, on Richta's part, ever deeper reduction of the critical potential of the original STR theory. He had to avoid some of the most crucial aspects previously emphasised by his theory and to abandon its "reformist" interpretation straight away (Richta \& Filipec 1971). None of his later works, therefore, contained any harsh criticism of planned, centrally administered economies. On the contrary, from then on he kept highlighting the unique opportunity that the centralised system offered for the full-fledged blossom of the STR. Furthermore, there was no more criticism of uniformity and conformism in education or public political discussions. The pressing calls for the development of radically new forms of labour also disappeared from his arguments. The theory was changed into a "developmental theory of technocratic governance and a legitimizing narrative for late socialist dictatorship" (Sommer 2016: 160). Its straight apologetic narrative assured the state socialist regime about the historically necessary superiority of the socialist organisation of social, political, and scientific life, and thus about the inevitability of their early takeover of the global competition in science and technology (Kedrov et al. 1974).

In the late 1960s and early 1970s the theory of STR was accompanied by a related academic discipline, the forecasting (or prognostics) that played a major role in the ideological critique of Western futurology and that expanded on its capacity for making predictions that the STR theory already envisioned (Sommer 2015). The increasing emphasis on the assimilation of socialism and science in STR and prognostics also entailed the growing role of science in the socio-scientific steering of society (védecké socialni rízení, nauchnoje upravlyenie obschestvom). This was a hot topic in Soviet political-philosophical literature from the 1970s (Afanasiev 1968, 1977;

${ }^{5}$ This interpretation draws on the "classical" account of Prague Spring history (Skilling 1976: 125-131); for the most recent study on Richta’s STR theory see Sommer 2016. 
Leninizm 1973). Authors admitted that in capitalism certain forms of social steering or social engineering had already been developed either in practice (Taylorism, Fordism) or in theory (T. Veblen, M. Weber). Nonetheless, they argued, in the case of socialism it should assume a much more systematic and society-wide scope. Whereas in capitalism the omnipresent monopolistic capital was the concealed subject of the steering, in socialism - under Party leadership - the historical subject of social steering was apparently the ever-growing strata of the working people. The practical consequence of this argument was the even more emphatic assertion of social scientific research as an indispensable component of communist governance.

The late socialist STR envisaged two fundamental levels of participation of science in social management. First, there was the development of long-term models and plans, including the development of five-year plans based on the prognoses of multidisciplinary teams. The second level concerned the design of specific solutions for "various levels of management work," which implied a wide range of applied social research and the development of "new complexes of sciences" such as demography, sociology, social psychology, various mathematical disciplines, cybernetics, etc. (Mikulinsky \& Richta 1982).

Much of the applied research and, above all, the forecasting, concerned economic planning and prognosis and centred in Czechoslovakia around the National Planning Commission (Sommer 2015). Let's leave this rather familiar part aside for now and focus on the other aspect of the forecasting business: namely, social planning and forecasting where different social sciences - with sociology on top - played a primary role. In historical memory today, the disciplines related to social planning have fallen into oblivion, partly due to the overall rise of economic rationality since the 1970s and, more specifically in the Czech and Slovak context, because it was the economic forecasters - such as Valtr Komárek, Miloš Zeman, and many others - and not the social forecasters who played an important role in the post-1989 transition.

Nevertheless, throughout the late socialist period the research complex of prognostics and social forecasting - considered to be the most complex and challenging element of forecasting - was not only rhetorically highlighted but also generously supported and funded. The main person to reformulate the STR scheme to reflect the needs of late socialist social management purposes in Czechoslovakia was, somewhat surprisingly, František Kutta, an economist and legendary mountaineer. In the 1960s Kutta joined Richta's team because he disagreed with the market-oriented 
approach of the team led by Ota Šik, which was drafting the economic reform. At the time Kutta was mainly concerned with material, technical, and technological aspects of economic growth in the "period of socialism expanding into communism" (Kutta 1962, 1968). Throughout the reformist 1960s he kept defending the superiority of central planning over any of the attempts to devise a mixed economy in Šik's fashion. In the 1970s Kutta found his place as the main ideologist of the "theory of management of social processes" developed as a part of the conservative late-communist theory of STR (Kutta 1971, 1974; Kutta et al. 1973). It was established on the wishful presumption that socialism, with its centrally organised economy and science, were paving the way towards sweeping technological innovation. Yet this first had to be made possible in the form of a "new, higher phase of development of socialist production based on higher principles of intensive growth" that involved all possible socio-economic factors. This complexity, Kutta maintained, highlighted the need for overall planning and a "management of social innovation process." This in itself was a complex process of multi-layered relations between science, equipment and technology, production, education, information flow, and, last but not least, effective management. To enable such development, the role of socialist state was to launch a transition towards "complex, systemic, long-term, optimal planning of social processes." A lot of hope was placed in the growing "automatisation and computerisation of information systems," which were supposed to solve, somewhat magically, the immense complexity of social processes (Kutta 1974: 611ff.).

Nevertheless, alongside such Marxist-Leninist scholastic theories, a whole range of practical disciplines and socio-techniques were developed in an effort to contribute to the umbrella project of social planning and social management, the aim of which was to direct and optimise major social processes in the desired direction of "advanced socialist society" and its future transformation into a communist one. This included economic sociology and the sociology or social-psychology of management, as well as the sociology of socialist way of life, and sociology of youth or of family. Although even in consolidated Czechoslovakia almost each of these sociological branches did develop its "grey-zone" alternative that tried to keep a low profile and stay away from direct ideological engagement (Nešpor 2014), their official representatives were very close to the hegemonic Marxist-Leninist social science discourse, in terms of its conceptual framework and language, as well as institutionally. The following part will focus on this kind of applied sociology for the purposes of authoritarian 
governance, which, as we shall see, might eventually have had quite different results and consequences in individual cases.

\section{/// Managing Society: The Sociology of Socialist Enterprise}

The theory of management was among the most "practical" disciplines in the field. Its main role was to help socialist managers and senior personnel to run enterprises and organisations. It had its own research institution, the Institute of Management, established in 1965 and operating throughout the state socialist era and into the liberal capitalist period. The Institute published two journals: Moderni rízení [Modern Management] and Organizace a rízeni [Organisation and Management]. Even the theory of management was not immune to the different ideological commitments. Particularly during the first years of the post-1968 consolidation many leading articles that appeared there focused on proving the Leninist roots of "modern socialist management." Most of the output of the Institute, however, was practice-oriented. The Institute also had a relatively free discussion on all possible modern management techniques and incentives arriving from the West or Asia. Nonetheless, this study is more concerned with theoretically informed applied sociological research reflecting the socialist management, operating fully within the Marxist-Leninist language code, and yet striving to work with some of the up-to-date sociological instruments.

The work of Jaroslav Kohout, a well-known sociologist working at the Prague-based University of Economics (Vysoká škola ekonomická, VŠE) is illustrative. Kohout, like many others, developed his theory of sociological and psychological aspects of economic micro-management in the 1960s (Kohout 1966, 1967). Already in his early works he was calling for a more academic approach to management through the incorporation of empirical and theoretical sociology and, simultaneously, for the development of a specific "socialist management theory independent from alien (read Western) models" (Kohout 1966). At the time, Kohout was the founder and first director of the Department of Sociology and Psychology at VŠE, which was actually the first department of the kind in Czechoslovakia. After 1968 he became the leading authority on enterprise sociology and the sociopsychology of management. Some of his works were considered of practical value despite his consequent application of the official Marxist-Leninist discourse and his loyalty to the Party (Kohout 1976, 1982). He became one of the leading practitioners of applied socialist social-management research in the service of the authoritarian rule. 
Here we are dealing with merely one aspect of Kohout's sociological thought - his theory of labour collectives and their key socialisation role in advanced socialist society (Kohout 1975, 1981). The theory leaned heavily on the classics of Marxism-Leninism, but also on contemporary Soviet authors such as the philosopher Victor G. Afanasiev or psychologists Nikolay S. Mansurov and Aleksander G. Kovalev. ${ }^{6}$ It drew on Marx's observation about the vital role of labour in the process of forming a human being. Historically, this has been a spontaneous process, which moulded human nature into a specific historical form shaped by the predominant production relations. Yet if the Marxist premise is that the social environment is the prime determinant of a human being, then human nature is always historically contingent. Thus in socialism the process of the "humanisation of man through labour" was to be transformed into a "managed" instead of a "spontaneous" process, since socialism aimed at the transformation and re-education of human beings, which was to remove all the negative legacies of the bourgeois past, including individualism and egotism. In the original teachings of Marx and Lenin before the Bolshevik revolution the re-appropriation of the rule of enterprise, together with mass social creativity and political organisation, was supposed to form the basis of a new communist constituent power, "the creative unity of the social, the economic, the political" (Negri 1999: 293). In late state socialism, in contrast, the industrial enterprise, still a crucial site of political interest, was seen as a potential major source of social stability. From the perspective of late socialist social management theory, the labour collective was to serve as the decisive plain for the "formation and development of the harmonious personality of socialist citizen." The Marxist-Leninist theoreticians hoped thus to fill the void in the ideological education of adults who were unaffected by either the state-educational or the Party-organisational institutions and mechanisms.

Socialist enterprise was thus to secure the production of utility values. Yet at the same time, it should also have been the primary site for the development of the "harmonious personality of a socialist citizen." Socialist enterprise, Kohout maintained, "does not fulfil one of its fundamental roles, unless it is an organisation form that puts in practice socialist collectivism." In practical terms, the author maintained, different forms of socialisation mechanisms should have been developed, along with various checks

\footnotetext{
${ }^{6}$ Not only did Kohout become the main proponent of the theory of labour collectives in the Czechoslovak context, but he was also an active force in the development of the field within the Soviet bloc; see Cherkasov \& Kohout 1979.
} 
and practices that would make it possible "to mould, in everyday factory practice, the working people according to the principles of socialist and communist society, and to educate them to such conduct, behaviour and reactions that are in compliance with these principles" (Kohout 1975: 33).

As some recent historical studies convincingly show, the reality in socialist enterprises was very far from the wished-for projections of the official Marxist-Leninist theoreticians and political representatives. Neither in the founding period nor at any later time, did the Party manage to really impose its presence on the industrial workers and, instead, remained alienated from its supposed power basis, which saw the Party simply as yet another "ruling class" (Heumos 2006; Kott 2014). The ensuing frustration was probably an additional incentive for the official social theoreticians to think over ways and means of reaching the labouring masses.

There was an effort - which eventually did not prove successful - to design special socio-techniques for factories and enterprises: for instance, by providing social analyses and steering instruments of the social climate, of interpersonal and inter-group relations. Furthermore, opinion polls in factories were conducted as a means to control the efficacy of decisionmaking at the management level. The polls were a kind of socio-technique that the Czechoslovak late-communist regime tried hard to use extensively. The government spared no funds or effort in this respect. At the same time, the polling research was one of the most closely monitored territories. Most of the empirical data concerning public opinions and attitudes was inaccessible not only to the general public, but often even to specialists from outside the institutions carrying out the empirical research, that is, mainly the two institutes for public polls, the federal and the Slovak one (Šiklová 2004). Their work was subordinated to the Department of Propaganda and Agitation of the Communist Party's Central Committee, for these institutes were defined and conceptualised primarily as service organisations for the highest Party leadership. Its aim was to provide, first, actual empirical data about the society and its changing attitudes for the purposes of governance and, second, to select data that would be - and indeed was - widely used as propaganda material in specialist publications and the daily press. ${ }^{7}$ Kohout's arguments about the appeal of opinion polls in enterprises and organisations followed the same top-down prophylactic

\footnotetext{
7 See, e.g., NA ČR (National Archives of the Czech Republic), KSČ-ÚV-02/4, file 54, a.u. 79/12, "Plán výzkumné činnosti ÚVVM na období 1978-1979" [ÚVVM research plan for 1978-1979]; ibid., file 6, a. u. 12/b3, "Informace o práci ÚVVM od roku 1977 a zaměření jeho činnosti v dalším období" [Information on the Work of ÚVVM from 1977 and its operational focus in the subsequent period].
} 
and propagandist logic. Opinion polls in labour collectives and research in interpersonal relations should have enabled managers and local Party leaders to develop differentiated, effective, and propaganda-oriented approaches to each workshop or department, and to focus on the most pressing issues. Simultaneously they should also have served as a control mechanism measuring the efficacy of managerial decision-making on the shop floor (Kohout 1975: 35).

\section{/// From a Sociology of the Socialist Way of Life Towards the "Civil Society" Paradigm?}

In the 1970s and 1980s various semi-official research endeavours or expert "niches" did not subscribe to the official, heavily ideologised sociological mainstream but still kept within the range of supportable topics. They stayed away from direct ideological engagement and instead tried to pursue empirically-oriented social research, leaning conceptually on nonMarxist-Leninist concepts and narratives. These included such fields as urban sociology, some areas of the sociology of enterprises, the sociology of youth and education, the sociology of family, or environmental sociology. In the self-reflexive history of sociology the "niches" could usually be read as attempts to retain some meaningful sociological research alongside - and often in spite of - the official, unproductive Marxist-Leninist sociological mainstream (Voříšek 2014). Such sociologists very often drew on impulses toward critical sociological thinking from the reformist 1960s, when Czech and Slovak sociology opened itself to international and transnational dialogue and was influenced by sociological thought and recent research from the West, and also from Poland, Yugoslavia, and the Soviet Union (Machonin 2005). This narrative certainly made sense to the many practitioners purged from academic sociology after 1968, who were forced to find jobs in strictly applied social-scientific research - if not outside the field altogether. They published under the names of their colleagues who "covered up" their works and, ultimately, produced sociological samizdat such as the journal Sociologicky obzor [Sociological Horizon], edited and written by Josef Alan and Miloslav Petrusek. It was from these sociologists and their milieus that the sociological mainstream emerged in the early liberal democratic period after 1989, when sociology was reconstituted as a critical academic reflection of modern society. Even then, sociology and sociological knowledge continued to serve largely as a "governance instrument" - 
both political and commercial - and gave birth, for instance, to a genuine opinion-poll industry in the post-communist period.

What remains questionable, though, is the image of the strict dividing line between, on the one hand, the "official" sociology that remained faithful to Marxist-Leninist teaching for whatever opportunistic reasons, and, on the other hand, those who refused to play along. It was precisely the "prognostic paradigm" and the different subsequent research and modelling schemes that played the role of an intermediary between the two worlds and was one of the main plains of convergence - if not conversion - of expert milieus in regard to the future (neo)liberal paradigm. Many of the aforementioned "niches" drew legitimacy, as well as state funding, from the argument that they, too, were contributing to the "social-scientific steering of society" by developing concrete modelling for the desired social-cultural development. This part of the niches' research arose from general prognostics and the conviction that empirical sociological research could provide data and techniques to regulate developmental trends in economic and social life. Such a picture somewhat questions the post-1989 quasi-dissident legend about "islands of positive deviation" in the "niches," which has been so much fostered by the founding generation of renascent sociology after the fall of communism. Most of the niche practitioners have so far paid limited attention to the argument of one from their midst, sociologist Jiří Kabele, that after all, "we were not a negligible part of the project of society-building and its scientific governance" (Kabele 2011). Such participation did not necessarily emerge from the practitioners' political attachment to the late-communist political order but rather from the generally accepted modernist presumption that societies can be thoroughly analysed and thus also governed scientifically.

An illustration is offered by the sociology of lifestyles or of "socialist way of life," a relatively recent discipline that emerged in the 1960s and was inspired by the Western sociology of lifestyles and leisure. In late communist Czechoslovakia, Blanka Filipcová was its chief proponent. Her redefinition of the field in the early 1970s started from a moderately interventionist position that sought the possibility of intervening in cultural education through partial control over leisure activities (Filipcová 1970; Filipcová \& Filipec 1976). Later her research assumed a more voluntarist and instrumental direction, looking for more direct possibilities for the ideological and political education (called consistently "socio-cultural formation") of socialist citizens through the management of their leisure activities. Notably even here, in the core of the official Marxist-Leninist 
sociology of socialist way of life, a discrepancy was identified between the socialist extensive model of development, which was based on systemic economic and quantitative indicators, and was seen as historically necessary (but overcome in the current situation), and the desired "intensive development model" based primarily on "social development preferring the development of resources and innovation" and thus on the "comprehensive development of socialist personality" (Filipcová 1984).

The official sociology of the socialist way of life was a relatively vast and well-funded research field with two major branches. The first, represented by Filipcová, focused on designing ideological models and offering grand interpretations, which were usually quite unrealistic. It sought ways to guide society not just to achieve its political acquiescence but to steer and stimulate labour, to motivate social engagement, and to increase the potential for innovation. The second branch, whose practitioners worked under the supervision of the former, involved strictly empirical research focusing usually on specific small areas: for instance, leisure activities within the military, teachers, or a particular issue of the lifestyle of working women.

As an intermediary effort between the two, a kind of middle-range prognostic modelling was developed by younger sociologists such as $\mathrm{Fe}-$ dor Gál and Zora Bútorová from the Bratislava-based Research Institute of Quality of Life, and Josef Alan from the Research Institute of Labour and Social Affairs in Prague. In the early 1980s these sociologists occupied themselves with developing the methodology of "dynamic modelling" and "dynamic prognosis" in social research and social management studies (Alan \& Gál 1981). They presented their approach as a significant element in the concretisation and more empirically based elaboration of the sociological category of "way of life," which was a prerequisite for any sensible "planning-like regulation of the development of socialist way of life" (Gál \& Bútorová 1981). The modelling, in their conceptualisation, had both explorative and normative aspects, where the "model-setter" (modelar) was more responsible for the former and the decision-maker (read Party or management leadership) for the latter. The planned design of the "dynamic way-of-life model" was sold to decision-makers as a potentially convenient instrument for eliminating the "aberrations (in social development) incongruous with the goal criteria" (ibid.: 435).

Thus "dynamic modelling" was supposed to be a more reality-based instrument for the very kind of social steering of socialist society that was preached by the official Marxist-Leninist forecasting theory, à la Kutta, and the official theory of socialist way of life, à la Filipcová. Yet the young 
sociologists were already at this point warning that dynamic modelling of social phenomena - similar to most other modelling approaches - still suffered from an overwhelmingly abstract approach. Thus they concluded their first analyses with an emphasis on the need for permanent feedback in the triad of prognosis-conception-planning, where the planners would continuously supply the forecasters with the changing input and also changing goals, and thus make prognosis considerably more flexible. Even more importantly, they accentuated the need for empirical analysis, which was much more likely to record the subjective and qualitative side of social reality and should function as a constant corrective to abstract mathematic and prognostic modelling (ibid.: 435-436).

Gál worked at the time with the Prague-based Sportpropag, an applied research institution founded by the Central Committee of the Czechoslovak Union of Physical Education (ČSTV), where a special Department for Complex Prognostic Modelling was established in 1981-1983, led by the economist Miloš Zeman. A typical "niche" organisation, the Department gathered under one roof a number of non-conformist scholars from a variety of disciplines such as economics, sociology, or ecology, and made relatively free discussion possible in its internal seminars until the whole Sportpropag was closed in 1984. Although a majority of its leading figures subscribed to some kind of systemic modelling and holistic forecasting, there was a small critical group of "apostates" from these methods, such as Josef Alan or Jiří Kabele. On their move from quantitative to qualitative sociological methods they questioned not just some aspects of the systemic paradigm but its entirety (Kabele 2011). These debates certainly influenced Gál, who - while continuing his critical work on dynamic modelling came to the conclusion that the "systemic dynamic modelling of social processes" must be altogether restructured if it was to survive as a viable sociological instrument (Gál 1984). At that point he was already on the way towards a more heterodox model of forecasting, the so-called "problemoriented participative forecasting" (POPF) which he developed together with associates such as Pavol Frič and Peter Benkovič (Gál 1989; Gál et al. 1988; Gál \& Frič 1987b).

The model originated from practical efforts to establish a different kind of forecasting in connection with the reorientation of Slovak scientific research. The task was to develop a general forecast for the scientific development of the Slovak Socialist Republic to 2010. The forecasters' team produced a large-scale interactive experiment involving general political directives, the directors of scientific institutes and heads of departments 
at the Academy of Science, and a relatively large group of rank-and-file researchers from a variety of fields - from the pure and natural sciences to human and social sciences (Gál et al. 1990; Gál \& Frič 1987a).

The general aim of POPF was to show "early signals of threats to development or to identify opportunities for development, but also to articulate interests and mobilise different social groups to act in a manner conducive to the elimination of such threats and the exploitation of such opportunities." As such, this type of forecasting - in contrast to the older kind of prognosis that focused on systemic factors and on imposing the forecast, based on collected data, "from above" - was constructed as a complex interactive process. It involved those who commissioned the forecast - usually managers and policy makers - the forecasting team, experts and professionals from the field concerned, and the public concerned - rank-and-file researchers, citizens of a town, factory workers, etc. (Gál \& Frič 1987b: 679).

A new element was the primary focus on forecasting as a way of active social learning and anticipatory behaviour. The participation of the broader public in the formulation of a forecast was to surpass the standardised "opinion polls for management purposes" elaborated by sociologists of enterprise such as Kohout. The POPF required an active collaboration of all the segments involved, plus continuous and interactive dialogue. "Thus it is a process of the gradual cultivation and articulation of opinions and adoptions of attitudes, rather than a once-only expression of one's standpoint" (ibid).

It was suggested that the method retained the traditional promise of social prognostics, i.e., the commitment to eliminate potential threats to harmonious social development. Moreover, there was also the promise of a possible moderate moulding of human minds in the process of a "gradual cultivation and articulation of opinions." Yet this process was double-sided, as it did not presuppose merely the imposition of directions from above, but also an articulation of interests and desires from below. Social dialogue was envisioned - which the authors did not explicitly call democratic. Not because that would be impossible but because it would be seen as a brazen critique of the "socialist democracy," which supposedly existed. The authors occasionally made their inherent criticism of late state socialist society somewhat more explicit when they argued, for instance, that in the "conditions of autocratic centralism" the POPF was not a viable concept, even though they were quick to assure the readers that their model was "not developed in the context of autocratic centralism." Yet if 
the model of POPF was to work, possible inhibitions in the social context had to be dealt with, such as the "distrust and unwillingness on the part of participants to express their interests and values," public indifference, or "the lack of readiness of the social system (sicl) to accept an open, critical and tension-ridden dialogue" (ibid.: 684).

The model was heterodox, while conditions in Czechoslovakia were relatively orthodox. From the broader perspective - though most probably independently - it was in congruence with the emerging democratisation discourse in Soviet prognostics of the perestroika period (Guth 2015). On the whole, however, despite a growing rhetorical adherence to the reformist perestroika language, the Czechoslovak sociology of social planning and programming, in its fundamental reasoning and ideological framework, remained faithful to a holistic, systemic, top-to-bottom approach, shielded by Marxist-Leninist references, as evidenced by a collective work of 1988, The Prognosis of the Social Development of Czechoslovak Society, which was part of a general long-term forecasting project (Illner et al. 1988).

The POPF was, in contrast, understood by its authors as a turn away from all-encompassing theoretical forecasting concepts presenting social systems as "entities governed by fully comprehensible laws of development" towards much more flexible, reality-checked, and local circumstances-adapted, participative models that presupposed ongoing communication between politicians, managers, specialists, and the population. They also assumed a fundamental plurality of interests and social positions that could hardly be made consonant with the Marxist-Leninist vision of a unified, homogenous socialist society. Albeit never explicitly used, the concept of "civil society" was lurking behind the POPF. Unsurprisingly, its authors were participants of different semi-official public initiatives such as the famed Bratislava nablas (Bratislava Out Loud) in 1987, which eventually gave rise to the Slovak democratisation movement culminating, in 1989, in the Public Against Violence with Fedor Gál as its first Chairman (Gál 1991).

The changing mood was tangible also in the POPF language of social analysis. On the one hand, the authors still retained many aspects of the official political - as well as scientific - language code, particularly in the conceptual repertoire of the prognostics. Yet they no longer used as many modelling or steering notions. Instead, somewhat surprisingly though significantly enough, they stated that one of their major motives, along with the "diagnosis of the causes" of certain critical situations, was also "the search for appropriate therapies" (Gál 1990: 74-82; Gál \& Frič 1987b: 685). 
The gradual transformation of the "social forecaster" into the "social therapist" was on the way.

\section{/// Conclusion}

What happened when the "social therapy" of social scientists encountered the economic "shock therapy" of the emerging political economic elite symbolised in Czech and Czechoslovak circumstances by Václav Klaus - is beyond the scope of this study. The nascent political elite of the liberal transition era in Czechoslovakia came from a relatively small number of dissident circles and expert groups such as the forecasters. The milieu of the non-conformist Sportprogag of the first half of the 1980s, where Fedor Gál met not only Miloš Zeman but also other future leading economists and politicians, including Václav Klaus, is a case in point. Many of the experts drifting towards democratisation movements at the end of the decade eventually became its leading figures or even leaders, such as Gál in the Public Against Violence from the very beginning, and Klaus in October 1990, after defeating his post-dissident opponents in the Civic Forum. In terms of political inclination, one can hardly speak of a single camp. Whereas Klaus started to push for neoliberal economic reforms, soon forming his own powerful liberal conservative Civic Democratic Party, the social forecasters and sociologists who emphasised the importance of the "social question" and the need for a well-structured and comprehensive social policy as an essential supplement to the economic transformation, leaned mostly towards some kind of social liberalism or social democracy. This is well proven, for instance, by a 1990 manifesto signed by the sociologists Alan, Gál, Kabele, Petrusek, Šiklová and a few others and sent to President Václav Havel (Problášení 2004). Gál, on top of all, was a conscious promoter of participatory social mechanisms and participatory democracy; his understanding of civil society was close to that of Havel. In contrast, Klaus' political credo, from very early on in the democratic era, contained a conscious defence of representative democracy and what he called a "standard system" of political parties as a counterweight to what he saw as suspect movement-like political formations and participatory democracy mechanisms. Nevertheless, what was shared throughout the broad "liberal democratic camp," at least at the beginning, was the belief in the need for radical, rapid, and all-encompassing change in the economy and society, which in the sociologists' vision should have helped to transform not only 
the centrally planned economy but also the fundamental models of social development (see, e.g., Gál 1991, 2000).

Most of the sociologists coming from semi-dissident or specialist circles were not economic neoliberals in their Weltanschaunng. Some of them, such as Jan Keller or Martin Potůček, became early critics of the liberal transition and its social cost. Yet in general sociology, like other human and social scientific disciplines in this period, transformed and accommodated itself to the new liberal democracy and capitalism. Its practitioners found their place in politics, remained in the academic sphere, or founded successful polling enterprises. In some ways, sociology adapted to the new circumstances even better than other social sciences, since empirical sociological research - which could build on the existing structures and expertise from the previous era - responded remarkably well to the requirements of the state administration or to commercial needs, either through publicly funded academic research or as private polling agencies (Nešpor 2014: 517-580).

If one understands governmentality as a genealogical concept soliciting historicising inquiry, one might agree that "even as the central elites may well conceive of the world using diverse narratives, so they often turn to forms of expertise to define specific discourses" (Bevir 2010: 438). In this article I have tried to explain the expertisation of governance during the late state socialist authoritarian rule in Czechoslovakia. In terms of the theory and practice of governance, the late-communist regimes developed peculiar theoretical disciplines rooted in modern social scientific research. Such policy had an awkward double edge ensuing from the nature of research creating critical knowledge for a client, i.e., the Party-state, but at the same time requiring autonomous space for the expert field and its internal discussion, which potentially went beyond the confined borders of the respective field. This study has explored a few examples of how society and social integration were studied and conceptualised - generally for the purposes of communist authoritarian governance - in the case of social planning studies, economic sociology and the sociology of labour, as well as the sociology of socialist style-of-life and the related middle-range prognostic methodology. After 1989, there was no notable follow-up to the academic work of some of the main protagonists such as Kutta, Filipcová, or Kohout, partly because of their age, but mostly, however, due to their alienation from the new emerging academic milieu in the liberal democratic system. Yet the same expert fields also produced a branch of socialscientific research that very soon came to be understood as an "alternative" 
sociological language and social thought, which was easily transformed into a new, non-Marxist sociological and social research paradigm. Fedor Gál predominantly used the paradigm for political and later commercial endeavours; others, such as Josef Alan or Pavol Frič, used it for notable academic projects in the new democratic regime.

\section{Acknowledgements:}

This article is a result of research funded by the Czech Grant Agency, GA15-14271S. The author wishes to express his gratitude to his student research assistants Vojtěch Pojar and Václav Rameš, as well as to the colleagues who commented widely on earlier drafts of the paper, Pavel Kolár̆, György Majtényi, Michael Voř́řsek, and two anonymous reviewers for Stan Rzeczy.

Bibliography:

/// Afanasiev V.G. 1968. Nauchnoje upravlyenie obshchestvom, Politizdat.

/// Afanasiev V.G. 1977. Chelovek v upravlenii obshchestvom, Politizdat.

/// Alan J., Gál F. 1981. "Možnosti a meze prognostického modelování," Sociologický ćasopis, vol. 1, pp. 51-64.

/// Andersson J. 2012. "The Great Future Debate and the Struggle for the World," The American Historical Review, vol. 117, pp. 1411-1430.

/// Andersson J., Rindzevičiūte E., eds. 2015. The Struggle for the Long-Term in Transnational Science and Politics: Forging the Future, Routledge.

/// Beissinger M. 1988. Scientific Management, Socialist Discipline, and Soviet Power, Harvard University Press.

/// Bevir M. 2010. "Rethinking Governmentality: Towards Genealogies of Governance," European Journal of Social Theory, vol. 13, pp. 423-441.

/// Cherkasov G.N., Kohout J., eds. 1979. Sociálni aspekty rízení pracounich kolektivu, Práce.

/// Filipcová B. 1970. "Sociologie volného času a společenská intervence," Sociologický ćasopis, vol. 1, pp. 1-6. 
/// Filipcová B. 1984. "Perspektivy způsobu života a intenzifikace společenského vývoje," Sociológia, vol. 4, pp. 386-396.

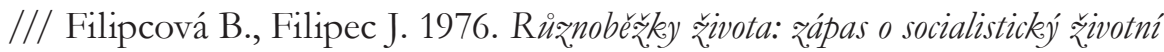
zpiosob, Svoboda.

/// Flew T. 2014. "Six Theories of Neoliberalism," Thesis Eleven, vol. 122(1), pp. $49-71$.

/// Gál F. 1984. "Problémy modelovania sociálných jevov metodami systémovej dynamiky," Sociologické časopis, vol. 1, pp. 77-85.

/// Gál F. 1989. "Problémovo orientovaný participatívny prístup," Sociologickéy cáasopis, vol. 3, pp. 302-311.

/// Gál F. 1990. Možnost’ a skutočnost', Obzor.

/// Gál F. 1991. Z prvej ruky, Archa.

/// Gál F. 2000. Vižie a ilúzie, Kalligram.

/// Gál F. et al. 1990. Prognózovanie vývoja vedy, VEDA.

/// Gál F., Bútorová Z. 1981. "Dynamické modelovanie a prognózovanie vybraných aspektov spôsobu života,” Sociológia, vol. 4, pp. 423-437.

/// Gál F., Frič P. 1987a. "Konceptuálné východiská prognózovania národnej vedy," Sociológia, no. 1, pp. 45-57.

/// Gál F., Frič P. 1987b. "Problem-Oriented Participative Forecasting: Theory and Practice," Futures, vol. 2, pp. 678-685.

/// Gál F., Frič P., Benkovič P. 1988. "Problémovo orientované participatívne prognózovanie," Trend, vol. 2, pp. 1-7.

/// Garlicki J. 1998. "System polityczny," [in:] Socjologia w Polsce, eds. Z. Krawczyk, K. Sowa, Wydawnictwo Wyższej Szkoły Pedagogicznej, pp. 143-166.

/// Guth S. 2015. "One Future Only: The Soviet Union in the Age of the Scientific-Technical Revolution," Journal of Modern European History, vol. 13, pp. 355-376.

/// Heumos P. 2006. Vyhrňme si rukávy, než se kola zastaví! Dèlníci a státni socialismus v Československu 1945-1968, Ústav pro soudobé dějiny AV ČR. 
/// Illner M. et al. 1988. Prognóza sociálního rozvoje československé společnosti, Ústav pro filosofii a sociologii ČSAV.

/// Kabele J. 2011. "Sportpropag - nepravděpodobné místo pro studium společnosti," Sociální studia, vol. 8, pp. 17-35.

/// Kedrov B.M., Richta R., Odujev S.P., eds. 1974. Clověke - věda - technika. $K$ marxisticko - leninské analýze VTR, Svoboda.

/// Kohout J. 1966. Sociologie a psychologie v hospodárské praxi, Nakladatelství politické literatury.

/// Kohout J. 1967. Sociologie a rízené ekonomiky, Práce.

/// Kohout J. 1975. “Aplikace sociální analýzy v řízení socialistických podnikových kolektivů," Sociologický časopis, vol. 1, pp. 26-37.

/// Kohout J. 1976. Sociální analýza a rízeneni socialistického podniku: v₹nik - pojetí - aplikace, Práce.

/// Kohout J. 1981. "K teorii pracovního kolektivu," Sociologický časopis, vol. 2, pp. 129-144.

/// Kohout J. 1982. Řizení pracounich kolektivư, Práce - Svoboda - Horizont.

/// Kott S. 2014. Communism Day-to-Day: State Enterprises in East German Society, University of Michigan Press.

/// Kutta F. 1962. Budování materiálnè technické základny komunismu, NPL.

/// Kutta F. 1968. Clověk-práce-technika, Práce.

/// Kutta F. 1971. "Vědeckotechnická revoluce - geneze a metodologie problému," Filosofický časopis, vol. 1, pp. 50-62.

/// Kutta F. 1974. "Principy sytému řízení sociálních procesů," Sociologický časopis, vol. 6, p. 611-625.

/// Kutta F., Soukup M. et al. 1973. Řizení v obdobi védeckotechnické revoluce: Principy socioekonomického rízení, Svoboda.

/// Lemke T. 2000. "Neoliberalismus, Staat und Selbsttechnologien: Ein kritischer Überblick über die governmentality studies, "Politische Vierteljabresschrift, vol. 41(1), pp. 31-47.

/// Leninizm 1973. Leninizm i upravlenie socialnymi processami pri socializme, Institut filosofii AN SSSR. 
/// Machonin P. 2005. Ceská společnost a sociologicképoznání. Problémy společenské transformace a modernizace od poloviny šedesátých let 20. Století do současnosti, ISV.

/// McCauley M., ed. 1987. Khrushchev and Khrushchevism, Macmillan Press.

/// Mikulinsky S.R., Richta R. 1982. Socialismus a věda, Academia.

/// Miller R.F., Féhér F., eds. 1984. Khrushchev and the Communist World, Croom Helm.

/// Negri A. 1999. Insurgencies: Constituent Power and the Modern State, University of Minnesota Press.

/// Nešpor Z. 2014. ““'Šedá zóna” v éře tzv. normalizace: Dům techniky ČSVTS Pardubice v dějinách české sociologie,” Sociologický časopis / Cžech Sociological Review, vol. 50(1), pp. 107-130.

/// Nešpor Z. et al. 2014. Déjiny české sociologie, Academia.

/// Petrusek M. 2014. ““'Socialistická věda” nebo "buržoazní pavěda”? Sociologie jako racionální konstruktivismus a jako radikální kritika," [in:] M. Petrusek, Marx, marxismus a sociologie, Sociologické nakladatelství, pp. 53-88.

/// Problásení sociologù (dopis prezidentovi). 2004. Sociologický časopis / Czech Sociological Review, vol. 40, pp. 763-764.

/// Puttkamer J.V. 2012. "Gesellschaftliche Selbstbeschreibungen und soziales Krisenbewusstsein in den ostmitteleuropäischen Volksrepubliken," [in:] Theorien und Experimente der Moderne. Europas Gesellschaften im 20. Jahrbundert, ed. L. Raphael, Böhlau, pp. 229-251.

/// Richta R., ed. 1966. Civilizace na roẓestí. Společenské a lidské souvislosti védeckotechnické revoluce, Svoboda.

/// Richta R. 1969. Civilization at the Crossroads: Social and Human Implications of the Scientific and Technological Revolution, International Arts and Sciences Press.

/// Richta R., Filipec J. 1971. Védecko-technická revoluce a socialismus, Svoboda.

/// Rindzevičiūte E. 2016. "A Struggle for the Soviet Future: The Birth of Scientific Forecasting in the Soviet Union," Slavic Review, vol. 75, pp. 52-76.

/// Rose N., Miller P. 1992. "Political Power beyond the State: Problematics of Government," The British Journal of Sociology, vol. 43, pp. 173-205. 
/// Rychtařík K. 1971. Sociologie v zápase o myšlení, Vojensko-politická fakulta VAAZ.

/// Šiklová J. 2004. "Nelegální výzkum veřejného mínění v období normalizace," Sociologický ćasopis, vol. 5, pp. 673-679.

/// Sirácky A. 1979. Doba a myslenie, Pravda.

/// Sirácky A., Rychtař́ík K. 1976. Sociológia myslenia a činu, Pravda.

/// Skilling H.G. 1976. Crechoslovakia's Interrupted Revolution, Princeton University Press.

/// Smith J., Ilic M., eds. 2011. Khrushchev in the Kremlin: Policy and Government in the Soviet Union 1953-1964, Routledge.

/// Sommer V. 2015. "Forecasting the Post-Socialist Future. Prognostika in Late Socialist Czechoslovakia, 1970-1989," [in:] The Struggle for the LongTerm in Transnational Science and Politics: Forging the Future, eds. J. Andersson, E. Rindzevičiūtè, Routledge, pp. 144-168.

/// Sommer V. 2016. "Scientists of the World, Unite! Radovan Richta's Theory of Scientific and Technological Revolution," [in:] Science Studies during the Cold War and Beyond: Paradigms Defected, eds. E. Aronova, S. Turchetti, Palgrave Macmillan, pp. 177-204.

/// Vořrišek M. 2012. The Reform Generation. 1960s Czechoslovak Sociology from a Comparative Perspective, Kalich.

/// Vořrišek M. 2014. "Česká sociologie sedmdesátých a osmdesátých let," [in:] Z. Nešpor et al., Déjiny české sociologie, Academia, pp. 358-384.

Archival materials:

/// NA ČR (National Archives of the Czech Republic), KSČ-ÚV-02/4, file 54, a.u. 79/12, "Plán výzkumné činnosti ÚVVM na období 1978-1979" [ÚVVM research plan for 1978-1979].

/// NA ČR (National Archives of the Czech Republic), KSČ-ÚV-02/4, file 6, a.u. 12/b3, "Informace o práci ÚVVM od roku 1977 a zaměření jeho činnosti v dalším období" [Information on the Work of ÚVVM from 1977 and its operational focus in the subsequent period]. 


\section{/// Abstract:}

This paper focuses on official Marxist sociology and social science research in Czechoslovakia as one of the central "disciplines of governance" in the 1970s and 1980s. With most of the first-class practitioners being purged after 1968, the study pays little attention to the intrinsic value of sociological production in the given period, but focuses instead on the modus operandi of "apologetic sociology": the ways in which sociological knowledge was used to help manage "socialist society" under the late-communist regime, and how that knowledge was adapted to the changes brought about by perestroika (while anticipating the discipline's own transformation during the early liberal democratic period after 1989). First, the paper deals with the reformulation, during the early 1970s, of Radovan Richta's theory of scientific and technological revolution from the originally reform-communist, emancipatory, and technology-optimistic concept of the 1960s into a hegemonic legitimation paradigm allied with the closely related social management theory elaborated by František Kutta. Then the paper addresses the more practical side of the paradigm, as exemplified by Jaroslav Kohout's economic sociology and his theory of labour collectives as central sites of state socialist socialisation and the disciplining of citizens. Finally, the paper considers semi-official research endeavours and expert "niches" during the 1980s, and how they drew legitimacy and state financial support from the claim that they were contributing to the "social-scientific steering of society" - while they stayed away from direct ideological engagement. It is these "niches" that formed the new sociological mainstream in the early liberal democratic period after 1989. That mainstream gave legitimacy not only to post-dissident social concepts such as "civil society" but also to the managerial and governance techniques of the emerging neoliberal capitalism. The paper exemplifies this branch of research by the mainly Bratislava-based group revolving around Fedor Gál and Pavol Frič and their development of a nonconformist method of "problem-oriented participative forecasting" during this period.

Keywords:

Czechoslovakia, forecasting, Marxist sociology, scientific and technological revolution, social management 
/// Michal Kopeček - head of the Department of Ideas and Concepts at the Institute of Contemporary History, Prague, and since October 2016, co-director of Imre Kertész Kolleg, Friedrich Schiller University in Jena. His research interests include comparative modern intellectual history of East-Central Europe, nationalism studies, the history of state socialism and communism, and the study of transition and democratisation processes. Among other works, he is author of the monograph In Quest of the Revolution's Lost Meaning: The Origins of Marxist Revisionism in Central Europe 1953-1960 (in Czech, 2009, forthcoming in English) and co-author of A History of Modern Political Thought in East-Central Europe, vol. I: Negotiating Modernity in the "Long Nineteenth Century" (2016).

Email:kopecek@usd.cas.cz 